\title{
Seroprevalence of Goatpox in Assam
}

\author{
Armanda-OO Pariat ${ }^{1}$, Durlav P. Bora ${ }^{1 *}$, Shyama P. Panda ${ }^{1}$, \\ Sabnam Ingtipi ${ }^{1}$, Lakshya Jyoti Dutta ${ }^{2}$ and Nagendra N. Barman ${ }^{1}$ \\ ${ }^{1}$ Department of Microbiology, College of Veterinary Science, \\ Assam Agricultural University, Khanapara, Guwahati-781 022, India \\ ${ }^{2}$ Department of ARGO, College of Veterinary Science, AAU, Khanapara, India \\ *Corresponding author
}

\section{A B S T R A C T}

\section{Keywords}

Sero-prevalance, Goatpox, Assam, Indirect ELISA

\section{Article Info}

Accepted:

23 April 2020

Available Online:

10 May 2020
Goatpox and Sheeppox are highly contagious, trans-boundary viral diseases of sheep and goats and are economically important causing high morbidity and mortality along with huge production loses. The disease was recorded for the first time from Assam in 2016 with high morbidity and mortality. No systematic vaccination policies are being followed so far against this disease. Therefore, the present study was undertaken to study the sero-prevalence of goatpox in goat population of Assam. Out of 220 serum samples collected from different parts of Assam, $157(71.36 \%)$ were found positive for goatpox antibody by Indirect ELISA. The difference in prevalence rates among the various districts was statistically significant $(\mathrm{p}<0.05)$. However, the difference in prevalence rates between young and adult animals and male and female animals were statistically not significant $(p>0.05)$. The present study concluded that goatpox infection is endemic in Assam indicated by high sero-positivity (71.36\%).

\section{Introduction}

Goatpox and Sheeppox are highly contagious, trans-boundary viral diseases of sheep and goats, respectively, caused by goatpox virus (GTPV) and sheeppox virus (SPPV) of the genus Capripoxvirus, sub-family Chordopoxvirinae of family Poxviridae (Van Regenmortel et al., 2000). GTPV is closely related to other members of the genus such as
SPPV and lumpy skin disease virus (LSDV). Diseases caused by members of the genus Capripoxvirus (Poxviridae) are Office Internationale des Epizooties (OIE) notifiable diseases (Bhanuprakash et al., 2011). Goatpox is often a great threat to goats and sheep and characterized by pyrexia, lacrymation, secondary bronchopneumonia with nasal discharges and generalised pock lesions with lymphadenopathy causing high 
mortality (50-100\%) and morbidity upto 100\% (Bhanuprakash et al., 2006; Babiuk et al., 2008). The disease is not distinguishable from sheeppox serologically but possible only by molecular technique (Hosamani et al., 2004). Indigenous sheep and goats exhibit some natural immunity, while the European breeds of sheep and goats are more susceptible to infection with these viruses (Heine et al., 1999). Goatpox and sheeppox infections are endemic in India and regular reports of outbreak episodes are available (Bhanuprakash et al., 2006, Venkatesan et al., 2010, Bhanuprakash et al., 2010, Verma et al., 2011, Bora et al., 2018).

In Assam, goat population showing pox like disease have been reported (Hopker et al., 2019) and tested positive for goatpox. The mortality and morbidity rate recorded was very high, up to $60-70 \%$ and $100 \%$ respectively (Unpublished data).

The disease has been reported for the first time in Assam and as such, no systematic vaccination policies are being followed so far against this disease. In such situations, a seroprevalence study on goatpox among the goat population of Assam may give an indication about the status of the disease and will help in formulating the control strategy to be applied against this disease.

\section{Materials and Methods}

\section{Serum sample}

Blood samples $(n=220)$ were collected from naturally infected and in contact apparently healthy goats of different parts of Assam and serum was separated and transferred immediately to $-20^{\circ} \mathrm{C}$ freezer for further investigation. Samples were collected throughout the year 2016-2018 to study the prevalence of the disease.

\section{Reference virus}

Goatpox virus (GTPV/Uttarkashi/P60) working seed strain in freeze dried form obtained from Pox Virus Laboratory, Indian Veterinary Research Institute, Mukteshwar Campus, Nainital, Uttarakhand was used in the present study.

\section{Revival and bulk production of goatpox reference virus}

Goatpox reference virus (GTPV/Uttarkashi/P$60)$ received in lyophilized form was revived in Vero cell line following the guidelines of OIE (OIE, 2010). Identity of the reference virus was checked based on characteristic CPE in Vero cells, amplification of Capripoxvirus specific full length P32 gene and PCR-RFLP based on full length P32 gene (Hosamani et al., 2004). Bulk production of the reference virus was carried out in confluent vero cell culture flasks $(300 \mathrm{cc})$.

\section{Purification of goatpox virus}

Goatpox virus was concentrated and purified by sucrose gradient centrifugation following standard method (Burleson et al., 1992). Briefly, the harvested cell culture fluid was subjected to centrifugation at $6000 \mathrm{rpm}$ for 10 minutes and supernatant was collected into a fresh container. PEG 6000 (Polyethylene glycol) was added to the collected supernatant at the rate of $8.0 \%(\mathrm{w} / \mathrm{v})$ and subjected to constant mixing under magnetic stirrer at $4{ }^{\circ} \mathrm{C}$ overnight. The sample was subjected to centrifugation at $6000 \mathrm{rpm}$ for 30 minutes and the resulting pellet was collected. The pellet was reconstituted in $8 \mathrm{ml}$ of $1 \mathrm{X}$ TE buffer $(10 \mathrm{mM})$ for homogenization and again centrifuged @ 7000 rpm for 4 minutes. The sample was overlaid onto $36 \%$ sucrose followed by ultracentrifugation at $85,000 \times \mathrm{g}$ for 1 hour. The resultant pellet was collected and again overlaid onto $60 \%$ and $36 \%$ sucrose 
gradient and subjected to ultracentrifugation @ $80,000 \times \mathrm{g}$ for 1 hour. The translucent layer interfacing the $60 \%$ and $36 \%$ layers containing the desired virus was collected and pelleted after diluting in $1 \mathrm{X}$ TAE buffer and stored at $-80^{\circ} \mathrm{C}$ till further use.

\section{Hyperimmune serum}

Anti Goatpox hyperimmune serum, raised in rabbit obtained from Pox Virus Laboratory, Indian Veterinary Research Institute, Mukteshwar Campus, Nainital, Uttarakhand was used in the present study.

\section{Indirect ELISA for detection of antibodies}

The prevalence of GTPV specific antibody in serum samples were tested by Indirect ELISA as per the method of Bhanuprakash et al., (2006) with some modifications. Briefly, the 96 wells microtitre ELISA plates (M/s Nunc, Polysorp) were coated with purified Goatpox virus with 1:1000 dilution (approx $1 \mu \mathrm{g} /$ well) in Carbonate-bicarbonate buffer ( $\mathrm{pH}$ 9.6). The diluted antigen $(50 \mu 1)$ was added to all the wells except antigen negative (Ag-ve) control wells, where $50 \mu 1$ of PBS was added.

The plates were incubated for 1 hour at $37^{\circ} \mathrm{C}$ and kept overnight at $4^{\circ} \mathrm{C}$. After incubation, the plates were washed thrice with washing buffer, PBS-T containing 0.05\% Tween-20. Test samples at 1:50 dilution, diluted in blocking buffer (PBS-T with 3\% LAH and $2 \%$ Skimmed Milk Powder) was used. 50 $\mu 1$ of diluted serum samples were added in duplicates into the sample wells and incubated at $37^{\circ} \mathrm{C}$ for 1 hour. (Wells A12 and B12 were kept as positive controls, C12 and D12 were kept as negative serum controls, E12 and F12 were kept as negative conjugate controls and G12 and H12 were kept as negative antigen controls). After incubation, the plates were washed thrice with washing buffer.
$50 \mu 1$ of diluted anti-goat HRPO conjugate (1:5000 dilution in blocking buffer) was added to each well except the negative conjugate control wells (E12 and F12) where $50 \mu 1$ of blocking buffer was added. The plates were again incubated at $37^{\circ} \mathrm{C}$ for 1 hour and washed thrice. $50 \mu \mathrm{l}$ of freshly constituted substrate solution was added to each well and incubate at $37^{\circ} \mathrm{C}$ for 15 minutes.

After 15 minutes, colour reaction was stopped by adding $50 \mu \mathrm{l}$ of $1 \mathrm{M} \mathrm{H}_{2} \mathrm{SO}_{4}$. Optical density (O.D) of the wells was measured at $492 \mathrm{~nm}$. Cut off value was based on negative serum reactivity as follows: (Mean O.D. value of test sample - Mean O.D. of negative sample) more than equal to $0.1(\geq 0.1)$ was considered as positive.

\section{Results and Discussion}

Goatpox is economically important disease in endemic regions like India. In Assam, we have recorded outbreaks of goatpox among the goat population of some districts (unpublished data). So, a seroprevalence study was designed to find out the overall prevalence of the disease. Clinically the disease is characterized by high fever, conjunctivitis and generalized pock lesions as well as associated with high morbidity and mortality (Bhanuprakash et al., 2010; Bora et $a l ., 2018)$. In the present study, the reference goatpox virus (GTPV/Uttarkashi/P60) virus was revived and purified for use as a coating antigen. The twenty-four hours confluent vero cell monolayer infected with Goatpox reference virus (GTPV/Uttarkashi/P60) in $300 \mathrm{cc}$ flasks showed cytopathic changes. Initiation of CPE was observed on day 2 post infection (2dpi) and kept under incubation until cell degeneration was observed.

The CPE was characterized by ballooning, increased refractility, formation of syncytia and detachment of the cells from the surface 
as reported earlier by many workers (Rao $e t$ al., 2000; Dutta et al., 2019; Bora et al., 2018; Madhavan et al., 2016). The propagation of the virus in the cells was further confirmed by amplification of partial P32 gene in the cell culture hervest which resulted in an expected product size of $390 \mathrm{bp}$ (data not shown). Infected vero cells were harvested by three cycles of freezing and thawing and the aliquots were processed for purification of the virus. The cell culture harvest was subjected to centrifugation for clarification and final purification of virus was carried out by sucrose discontinuous gradient ultracentrifugation. A major purified virus band as a well-defined opalescent zone was seen between $60 \%$ and $36 \%$ sucrose layer. The virus pellet obtained was finally suspended in required volume of $1 \mathrm{X}$ TAE buffer, collected and stored at $-20^{\circ} \mathrm{C}$ till further use for use as coating antigen. In the present study, blood samples were collected from naturally infected and in contact apparently healthy goats of Assam.

Table.1 Detection of Goatpox Viral Antibody in Serum Samples by Indirect Elisa

\begin{tabular}{|c|c|c|c|}
\hline District & Total no. of samples & Total positive & \% positivity \\
\hline Kamrup & 76 & 51 & 67.11 \\
\hline Karbi Anglong & 66 & 50 & 75.75 \\
\hline Nagaon & 17 & 11 & 64.71 \\
\hline Sonitpur & 8 & 6 & 75 \\
\hline Dhubri & 6 & 5 & 83.33 \\
\hline Morigaon & 14 & 9 & 64.29 \\
\hline Darang & 23 & 17 & 73.91 \\
\hline Nalbari & 10 & 8 & 80 \\
\hline TOTAL & $\mathbf{2 2 0}$ & $\mathbf{1 5 7}$ & $\mathbf{7 1 . 3 6}$ \\
\hline
\end{tabular}

Table.2 Sex wise prevalence of goatpox viral antibodies

\begin{tabular}{|l|c|c|c|}
\hline \multicolumn{1}{|c|}{ Sex } & $\begin{array}{c}\text { Number of samples } \\
\text { Collected }\end{array}$ & $\begin{array}{c}\text { Number of Positive } \\
\text { Samples }\end{array}$ & $\begin{array}{c}\text { Prevalence } \\
(\boldsymbol{\%})\end{array}$ \\
\hline Male & 86 & 58 & 67.44 \\
\hline Female & 134 & 99 & 73.88 \\
\hline
\end{tabular}

Table.3 Age wise prevalence of goatpox viral antibodies

\begin{tabular}{|c|c|c|c|}
\hline Age & $\begin{array}{c}\text { Number of samples } \\
\text { Collected }\end{array}$ & $\begin{array}{c}\text { Number of Positive } \\
\text { Samples }\end{array}$ & $\begin{array}{c}\text { Prevalence } \\
(\%)\end{array}$ \\
\hline Adult & 145 & 93 & 64.13 \\
\hline Young & 75 & 64 & 85.33 \\
\hline
\end{tabular}




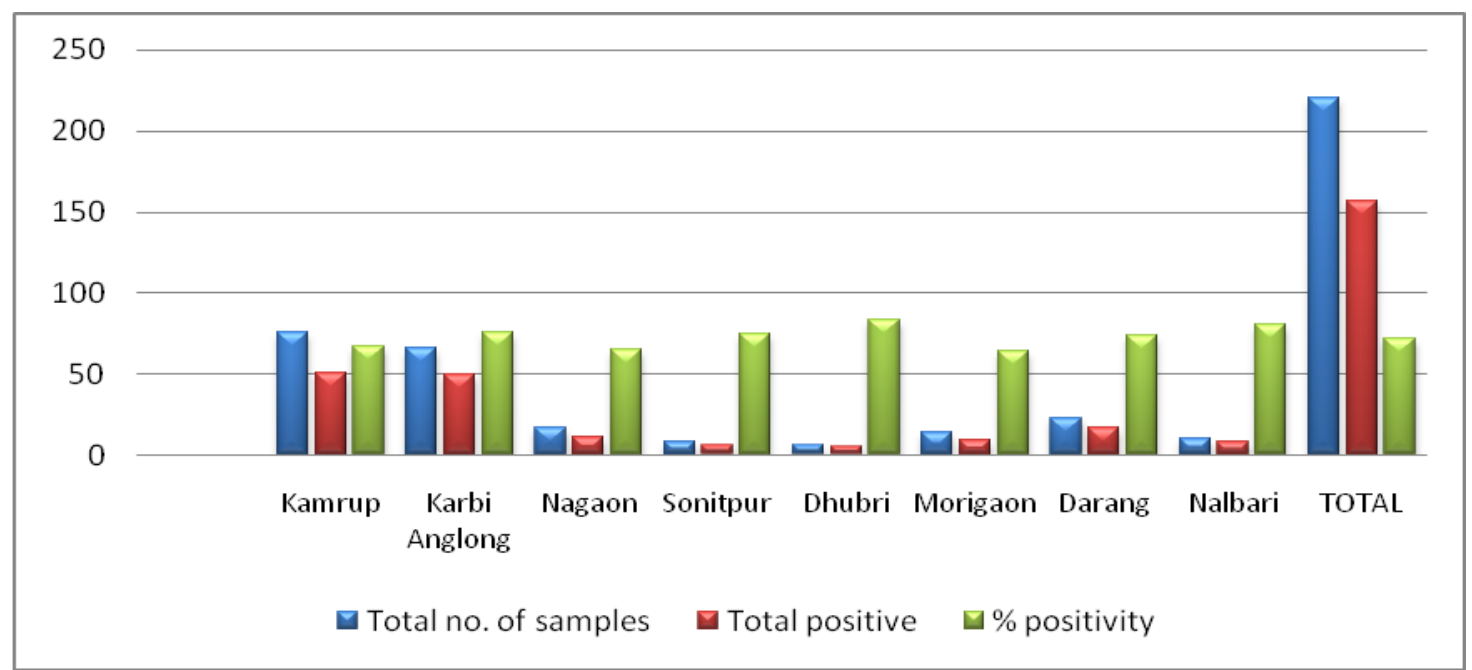

Fig.1 Graph representing place of collection, total number of positive serum samples and percent positivity of prevalence of goatpox viral antibody from different districts of Assam

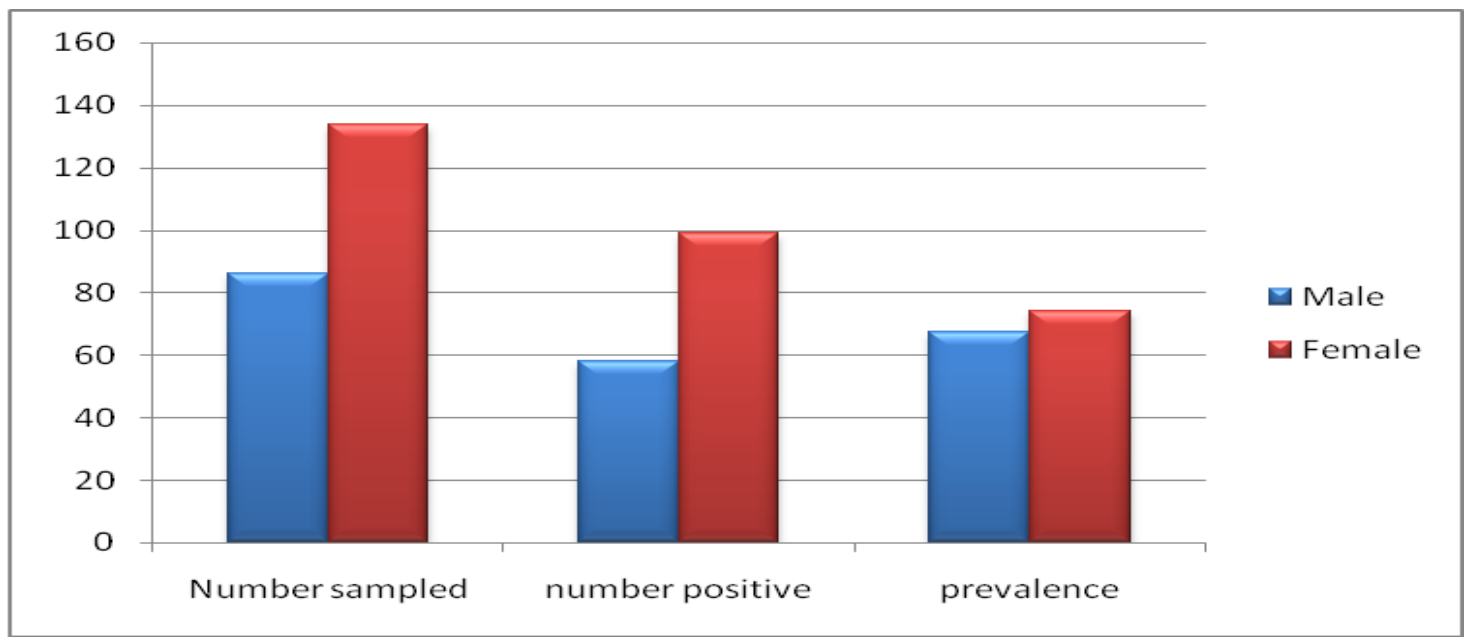

Fig.2 Graph representing sex-wise prevalence of goatpox viral antibody

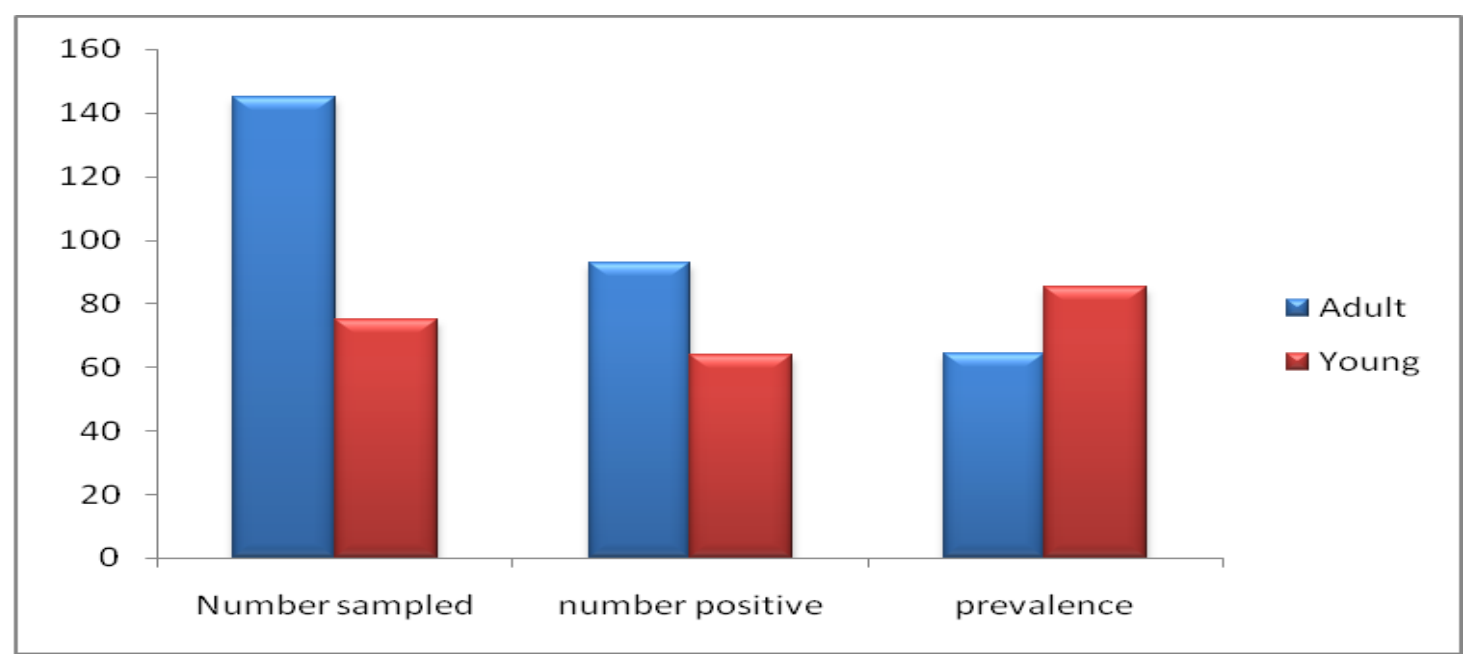

Fig.3 Graph representing age-wise prevalence of goatpox viral antibody 
A total of 220 serum samples (Table 1) were collected from 8 districts of Assam, out of which 157 were found positive for Goatpox viral antibody by Indirect ELISA with a percent positivity of $71.36 \%$ (Table 1, Fig. 1). Highest percentage of samples having positive Goatpox viral antibody was recorded from Dhubri district of Assam (5/6) with a percent prevalence of $83.33 \%$ and lowest was recorded from Morigaon district of Assam (9/14) with a percent positivity of $64.29 \%$.

The difference in prevalence rates among the various districts was statistically significant at $5 \%$ level of significance $(\mathrm{p}<0.05)$. Age and sex wise study revealed that, goatpox was more prevalent in young animals $(85.33 \%)$ as compared to adults $(64.13 \%)$ (Table 2, Fig. 2) while prevalence was higher in females (73.88\%) as compared to males $(67.44 \%)$ (Table 3, Fig. 3). However, the difference in prevalence rates between young and adult animals and male and female animals were statistically not significant $(\mathrm{p}>0.05)$.

Indirect ELISA and immune precipitation tests were optimized to detect goatpox virus specific antibody as well as virus antigen (Sharma et al., 1988, Bhanuprakash et al., 2006b). In our study, indirect ELISA was applied to screen the prevalence of goatpox in the goat population of Assam. However, the study was confined only to those districts where clinical cases of goatpox were recorded, depicting a clear picture of seropositivity of goatpox antibodies among the goat population.

Goatpox was recorded in Assam for the first time in 2016 (unpublished data), and as such no systematic vaccination is followed by the farmers. The presence of GTPV specific antibody in sera indicates the occurrence of goatpox in these animals. In seroprevalance studies, applications of indirect ELISA have been well documented (Bora et al., 2016,
Garam et al., 2016). In the present study, the overall seroprevalence of the goats against GTPV was considerably higher (71.36\%), which may be due to the exposure of these animals to the virus, recovered or becoming symptomless carrier. Similar observations were also recorded by previous workers (Bora et al., 2016, Gokce et al., 2005). Considering the age group, the highest prevalence of GTPV-specific antibodies was found in the young age group $(85.33 \%)$ in comparison to adults.

Similaly, sex wise, GTPV specific antibodies were more prevalent in females $(73.88 \%)$ than males. However, the difference in prevalence rates between young and adult animals and male and female animals were statistically not significant at $5 \%$ level of significance ( $>00.05)$. The present study is a preliminary one involving few districts of Assam. Collection of more number of samples from goat covering all the districts will be required to elucidate the exact epidemiological picture of goatpox in Assam.

\section{Acknowledgements}

The authors thank the field veterinary officers of all the places of outbreak for the timely information and help rendered during collection of samples. The financial support provided by DBT, India under North-East Twinning program on DBT-NER on Pox project $(\mathrm{BT} / 385 / \mathrm{NE} / \mathrm{TBP} / 2012)$ is also acknowledged.

\section{References}

Babiuk, S., Bowden, T. R., Boyle, D. B., Wallace, D. B. and Kitching, R. P. (2008). Capripoxviruses: An emerging worldwide threat to sheep, goats and cattle. Transboundary and emerging Diseases 55(7): 263-272.

Bhanuprakash, V., Hosamani, M. and Singh, 
R. K. (2011). Prospects of control and eradication of capripox from the Indian subcontinent: a perspective. Antiviral research 91(3): S225-232.

Bhanuprakash, V., Hosamani, M., Juneja, S., Kumar, N. and Singh, R. K. (2006). Detection of goat pox antibodies: comparative efficacy of indirect ELISA and counter immune electrophoresis. Journal of Applied Animal Research 30(2): 177-180.

Bhanuprakash, V., Venkatesan, G., Balamurugan, V., Hosamani, M., Yogisharadhya, R., Chauhan, R.S., Pande, A., Mondal, B. and Singh, R.K. (2010). Pox outbreaks in sheep and goats at Makhdoom (Uttar Pradesh), India: evidence of sheeppox virus infection in goats. Transboundary and emerging diseases 57(5): 375-382.

Bora, D P, Venkatesan, G, Neher, S., Mech, P., Barman, N N, Ralte, E., Sarma, D. and Das, S K (2018). Goatpox outbreak at a high altitude goat farm of Mizoram: possibility of wild life spill over to domestic goat population. Virus Dis. 29(4): 560-564.

Bora M, Bora DP, Barman NN, Borah B, Das $S$ (2016). Seroprevalence of contagious ecthyma in goats of Assam: An analysis by indirect enzyme-linked immunosorbent assay, Veterinary World, 9(9): 1028-1033.

Burleson, F. G., Chambers, T. M. and Wiedbrauk, D. L. (1992). Virology: a laboratory manual. Academic Press, San Diego.

Dutta TK, Roychoudhury P, Kawlni L, Lalmuanpuia J, Dey A, Muthuchelvan D, Mandakini R, Sarkar A, Ramakrishnan MA, Subudhi PK (2019). An outbreak of Goatpox virus infection in Wild Red Serow (Capricornis rubidus) in Mizoram, India. Transbound Emerg Dis. 66(1):181-185.

Gokce, H.I., Genc, O. and Gokce, G. (2005)
Seroprevalence of contagious ecthyma in Lambs and humans in Kars, Turkey. Turk. J. Vet. Anim. Sci., 29: 95-101.

Garam GB, Bora DP, Borah B, Bora M, Das SK (2016) Seroprevalence of Rotavirus infection in pig population of Arunachal Pradesh, Veterinary World, 9(11): 13001304.

Heine, H. G., Stevens, M. P., Foord, A. J. and Boyle, D. B. (1999). A capripoxvirus detection PCR and antibody ELISA based on the major antigen P32, the homolog of the vaccinia virus $\mathrm{H} 3 \mathrm{~L}$ gene. Journal of immunological methods 227(1-2): 187-196.

Hosamani, M., Mondal, B., Tembhurne, P. A., Bandyopadhyay, S. K., Singh, R. K. and Rasool, T. J. (2004). Differentiation of sheep pox and goat poxviruses by sequence analysis and PCR-RFLP of P32 gene. Virus genes 29(1): 73-80.

Hopker, A Pandey, N., Saikia, D, Goswami, J., Hopker, S., Saikia, R. and Sargison, N (2019). Spread and impact of goat pox (Bsagolay bohonta) in a village smallholder community around Kaziranga National Park, Assam, India. Tropical Animal Health and Production 51:819-829

Madhavan, A., Venkatesan, G. and Kumar, A. (2016). Capripoxviruses of small ruminants: Current updates and future perspectives. Asian J Anim Vet Adv. 11: 757-770.

OIE (Office International des Epizooties) (2010). Manual of Diagnostic Tests and Vaccines for Terrestrial Animals.

Rao, T. V. S. and Bandyopadhyay, S. K. (2000). A comprehensive review of goat pox and sheep pox and their diagnosis. Animal health research reviews 1(2): 127-136.

Sharma, B., Negi, B.S., Yadav, M.P., Shankar, H. and Pandey, A.B. 1988. Application of ELISA in the detection of goat pox antigen and antibodies. 
Acta. Virol., 32: 65-69

van Regenmortel, M., Mayo, M., Fauquet, C. and Maniloff, J. (2000). Virus nomenclature: consensus versus chaos. Arch. Virol. 145, 2227-2232.

Venkatesan G, Balamurugan V, Singh R. K, Bhanuprakash V (2010). Goat pox virus isolated from an outbreak at Akola, Maharashtra (India) phylogenetically related to Chinese strain. Trop. Anim. Health Prod. 42: 1053-1056. Verma S, Verma LK, Gupta VK, Katoch VC, Dogra V, Pal B, Sharma M.(2011). Emerging Capripoxvirus disease outbreaks in Himachal Pradesh, a northern state of India. Transbound Emerg Dis 58 (1): 79-85.

\section{How to cite this article:}

Armanda-OO Pariat, Durlav P. Bora, Shyama P. Panda, Sabnam Ingtipi, Lakshya Jyoti Dutta and Nagendra N. Barman. 2020. Seroprevalence of Goatpox in Assam. Int.J.Curr.Microbiol.App.Sci. 9(05): 2726-2733. doi: https://doi.org/10.20546/ijcmas.2020.905.312 